\title{
Nursing training in Brazil and in Portugal: similarities and specificities
}

\section{Brazil and Portugual: nursing training}

\author{
Silvana Sidney Costa Santos ${ }^{1 *}$, Manuel José Lopes ${ }^{2}$, Ana Fonseca ${ }^{3}$, \\ Gertrudes Silva ${ }^{4}$, Elizabeth Teixeira ${ }^{5}$
}

\begin{abstract}
Objective: To identify similarities/specificities in the nursing training in Brazil and in Portugal. This is a documentary research conducted in two higher education institutions, in January 2013. Method: It was focused on the National Curriculum Guidelines and on the Bologna Process. Results: Common points: objectives and profile of the newly-trained nurses grounded on competencies; teaching of education in/for health. Brazilian specificity: universal admission; three disciplines focused on research; mandatory discipline related to elderly care; two optional disciplines: Alternative therapies and Brazilian Language of Signs; insertion of complementary activities, actions in teaching/research/extension; basis of teaching: compliance with the Brazilian Unified Health System. Portuguese Specificity: admission with regionalized medical certificate; grounded on the European Credit Transfer and Accumulation System; compulsory disciplines: Clinical Reasoning in Nursing; Family Nursing; Development throughout life; Rehabilitative Nursing and Prospects of development of the Nursing; two optional disciplines: entrepreneurship and arts; basis of teaching: clinical teaching. Conclusions: There are similarities and specificities between the surveyed courses.
\end{abstract}

Descriptors: Teaching; Curriculum; Nursing Education; Training; Nursing

\section{Formação do enfermeiro no Brasil e em Portugal: aproximações e especificidades \\ Brasil e Portugual: formação do enfermeiro \\ RESUMO}

Objetivo: Identificar aproximações/especificidades na formação do enfermeiro no Brasil e em Portugal. Pesquisa documental em duas instituições de educação superior, em janeiro de 2013. Método: Centrou-se nas Diretrizes Curriculares Nacionais e no Processo de Bolonha. Resultados: Pontos comuns: objetivos e perfil dos egressos pautados em competências; ensino da educação em/para a saúde. Especificidade brasileira: ingresso universal; três disciplinas voltadas à pesquisa; disciplina obrigatória cuidado ao idoso; duas disciplinas optativas: Terapias alternativas e Linguagem Brasileira de Sinais; inserção de atividades complementares, ações em ensino/pesquisa/extensão; base do ensino: atendimento ao Sistema Único de Saúde. Especificidade portuguesa: ingresso com atestado médico e regionalizado; pautada no Sistema Europeu de Transferência de Créditos; disciplinas obrigatórias: Raciocínio clínico em Enfermagem, Enfermagem da família, Desenvolvimento ao longo da vida, Enfermagem de Reabilitação, Perspectivas de desenvolvimento da enfermagem; duas disciplinas optativas: empreendedorismo, artes; base do ensino: ensino clínico. Conclusões: Há aproximações e especificidades entre os cursos.

Descritores: Ensino; Currículo; Educação em Enfermagem; Formação; Enfermagem

\section{Formación de enfermeros en Brasil y Portugal: enfoques y especificaciones \\ Formación de enfermeros en Brasil y Portugal}

\section{RESUMEN}

Objetivo: El objetivo del estudio fue identificar enfoques/especificidad de la educación de enfermería en Brasil y Portugal. Metodología: Documental de investigación en dos instituciones de educación superior, en enero de 2013. Centrado en las Directrices Curriculares Nacionales y el Proceso de Bolonia. Resultados: Los puntos comunes: objetivos y el perfil de los graduados en la enseñanza de habilidades forrado educación /salud. Brasileño Especificidad: admisión universal, impulsadas por la investigación disciplinas; obligatoria cuidados a los ancianos, los cursos electivos: Terapias Alternativas y Lengua Brasileña de Señales, inserción de actividades complementarias, las acciones de docencia / investigación/ extensión, la educación básica: Sistema de Cuidado Salud entrada Especificidad portugués con certificado médico y regionalizada; guiado en la transferencia de créditos europeo; asignaturas obligatorias: Razonamiento clínico en Enfermería, enfermería Familiar, desarrollo permanente, enfermería en Rehabilitación, Perspectivas dedesarrollo de la enfermería; dos cursoselectivos: el espíritu empresarial, las artes, la educación básica: la enseñanza clínica. Conclusiones: Existen similitudes y especificidades entre los cursos.

Descriptores: Enseñanza; Currículo; Educación; Enfermería; Educación; Enfermería

${ }^{1}$ Enfermeira. Doutora em Enfermagem. Universidade Federal do Rio Grande. Programa de Pós-Graduação em Enfermagem, Rio Grande, RS, Brasil. E-mail: silvana.sidney@gmail.com

${ }^{2}$ Enfermeiro. Doutor em Enfermagem. Universidade de Évora. Escola Superior de Enfermagem de São João de Deus, Évora, Portugal. E-mail: mjl@uevora.pt

${ }^{3}$ Enfermeira. Mestre em Educação. Universidade de Évora. Escola Superior de Enfermagem de São João de Deus, Évora, Portugal. E-mail: afonseca@uevora.pt

${ }^{4}$ Enfermeira. Mestre em Educação. Universidade de Évora. Escola Superior de Enfermagem de São João de Deus, Évora, Portugal. E-mail: gs@uevora.pt

${ }^{5}$ Enfermeira. Doutora em Desenvolvimento Sustentável do Trópico Úmido. Universidade do Estado do Pará. Programa de Pós-Graduação em Enfermagem. Pará, Brasil. E-mail: etfelipe@hotmail.com

* Autor correspondente: Silvana Sidney Costa Santos: Rua Duque de Caxias, 197/503. Centro. Rio Grande, RS, Brasil. CEP: $96200-020$ 


\section{INTRODUCTION}

In Brazil, the training of nurses has been marked by reforms and different legal milestones. The integration to the higher education was obtained after approval of the Law $n^{\circ} 775$, published in $1949^{(1)}$. With the approval of the Law of Directives and Basis for National Education, $n^{\circ}$ 9.394, of 12/20/1996 ${ }^{(2)}$, the restructuring of the undergraduate courses, the extinction of the minimum curricula and the adoption of curricular guidelines specific for each course were determined.

After a joint mobilization of the Brazilian nurses, encouraged by the Brazilian Nursing Association (ABEn, as per its acronym in Portuguese), the National Curriculum Guidelines (DCNs, as per its acronym in Portuguese) were approved for the Undergraduate Nursing Course (3), Resolution 03/2001, with the suggestion that the Policy Project of Course (PPC, as per its acronym in Portuguese) was built collectively. The PPC should present: flexibility, emphasis on comprehensive training, incorporation of complementary activities, insertion of interdisciplinary practices, predominance of training over information, articulation between theory and practice, inseparability among teaching, research and extension, diversification of learning fields and active methodologies ${ }^{(4)}$, where the student is put in the core of the teaching and learning process.

The DCNs indicate that the PPCs, with their curricular structures, are able to construct an academic and professional profile with the competencies, skills and contents within contemporary perspectives and approaches of training, compatible with national and international references, thereby enabling nurses to act with quality, efficiency and solvability in the scope of the Brazilian Unified Health System (SUS, as per its acronym in Portuguese).

In 2009, the resolution Cne/Ces $n^{\circ}$ 04, of April $6^{\text {th }}$, 2009, was approved, which established the minimum hourly load and the procedures relating to the integralization in the face-to-face modality, which left the Nursing with a minimum of 4.000 hours, with integralization of five years in ten academic semesters $^{(5)}$.

In 2012, 838 undergraduate nursing courses were registered in the Brazilian Ministry of Education, being that more than $45 \%$ of them were located in the Southeast Region and more than $80 \%$ belonged to the private network. The need for new nurses is a reality, but it is necessary that these professionals are trained in a quality process aimed at meeting the multiple and growing social and sanitary demands. It is not enough to recognize the importance of expanding the number of nurses for the market, if these professionals did not show a pattern that complies with the necessary requirements to meet the health care demand of the population ${ }^{(6)}$.

Nowadays, the Nursing training is a question that mobilizes Brazilians nurses and was a topic of discussion during the $13^{\text {th }}$ National Seminar on Guidelines for Nursing Education, promoted by the Brazilian Nursing Association in 2012, where the "Letter of Belém/PA, for the Brazilian Nursing Education", was approved, on September $1^{\text {st }}, 2012^{(7)}$.

The Letter of Belém highlights the concern with the expansion of quantity rather than the quality of training of the Brazilian nurses; brings questions related to the supervised internship of students, which should have the participation of the nurses of the services; encourages the training in licentiate in nursing attached to the bachelor course; requires from the Federal Nursing Council the denial of registration of nurses and technicians, which are the only Nursing teaching modalities recognized in the country, whose courses have been conducted by means of distance learning (EAD, as per its acronym in Portuguese ${ }^{(8)}$.

In Portugal, over time, the training of nurses was also marked by reforms and different legal milestones. With the publication of the Decree-law $n^{\circ} 480 / 88$, of December $23^{\text {rd }}, 1988$, the integration of the Nursing training in the Polytechnic Higher Education took place. This constitutes a fundamental milestone in the history of the Portuguese nursing because it produced the conditions for the development of the Nursing, whether as a discipline or as a profession ${ }^{(9)}$.

In the two decades after that, transformations in the whole higher education of the country took place, more particularly in the nursing teaching. Thus, a period of adequacy to the demands arising from the insertion of the course into the higher education came after another one that brought deep transformations with the beginning of the implementation of the Bologna process. This process had the Sorbonne Declaration (1998) and the Bologna Declaration (1999), among others, as its remarkable moments.

The Bologna Process aimed at promoting a generalized harmonization of educational structures, 
which ensure the higher trainings in a Europe comprised of 45 countries. Within this framework, the higher education systems should be equipped with a structural organization with similar basis, offering courses and specializations similar and comparable in terms of content and duration, besides providing certificates with an admittedly equivalent value, both academically and professionally.

In 2005, Portugal started the transformations inherent in the Bologna process, with the publication of the certificate that regulates the instruments for the creation of the European Space for Higher Education ${ }^{(10)}$, a new system of credits (ECTS, as per its acronym in the original language) for the cycles of studies and mechanisms of mobility, among others. In that same year, the Law on the Education System was changed, contemplating the bases for implementation of the Bologna Process in the Higher Education. A generic framework of qualifications, organized in three cycles of study (licentiate, master and doctoral), was defined. Generic qualification descriptors for each cycle were also defined, based on acquired competencies, as well as the structure of $1^{\text {st }}$ and $2^{\text {nd }}$ cycles of studies in terms of ECTS intervals ${ }^{(10)}$.

In 1998, the Order of Nurses was founded, which is constituted as a professional association of public law and has the fundamental purpose of promoting the defense of the quality of nursing care provided to the population, as well as the development, regulation and control of the exercise of the nursing profession, thereby ensuring the compliance with the rules of ethics and professional deontology.

Due to the fact that Brazil and Portugal are two Portuguese-speaking countries, with certain proximity and exchanges between nursing teachers and students and in the face of these reflections, the following research questions were raised: what are the differences between the nursing training in Brazil and in Portugal with regard to course objectives, profiles of students, competencies, modalities of admission and curricular structures? What are the similarities between the teaching method applied of the nursing courses in Brazil and in Portugal? What are the characteristics/ differences between the training courses for nurses in Brazil and in Portugal?

The objective of this paper was to identify similarities and specificities in the nursing training in two courses in Brazil and in Portugal.

\section{Method}

This is a documentary study. The documentary research makes use of methods and techniques for seizure/comprehension/analysis of documents of a wide variety of types, printed and scanned. It is a type of study that substantially eliminates the influence of the context experienced by the researcher, as well as of the surveyed happenings or behaviors, thereby suppressing the possibility of reaction of the subject towards the evolution of the facts ${ }^{(11)}$.

The sample was represented by two nursing courses, one from Brazil and another from Portugal, due to being the courses in which some authors are inserted. The Brazilian nursing course is from the Nursing School of the University of Rio Grande (FURG, as per its acronym in Portuguese), located in the city of Rio Grande, Rio Grande do Sul, Brazil, authorized in $08 / 20 / 1975$, which started its activities in the first academic semester of 1976, with recognition by means of the Decree 1.223/79. The Nursing Department of the FURG was created in February 1997. In 2003, the Graduate Nursing Program was started, with the Master Course. In 2008, after the restructuring of the FURG, the Nursing School emerges as organic educational unit. In 2009, the Doctorate Course was started. It has two multiprofessional residences, one focused on the hospital scope and another on the community environment. It has 29 teachers, with 18 doctors and 11 masters (some of them are completing the doctorate degree); four administrative technicians, four nurses responsible for monitoring the supervised internships and about 320 undergraduate students, plus 100 in master and doctoral degrees, besides approximately 30 attending the residences.

The Portuguese nursing course operates at the São João de Deus Nursing School (ESESJD, as per its acronym in Portuguese), located in the city of Évora, South Region of Portugal (Alentejo). In addition to the licentiate nursing course, three master nursing courses are offered in the ESESJD: Mental Health and Psychiatry, Community Health, Maternal Health and Obstetrics; three post-licentiates of specialization in Nursing of: Rehabilitation, Medical-Surgical, Pediatrics and Child Health, which are constituted as sufficient condition for granting the title of clinical specialist in the respective area, registered in a professional card, by the Order of Nurses; four graduate courses: Supervision in Nursing, Chinese 
Medicine, Intervention in Wounds and Integrated Continued Care. There are 26 teachers, where eight are doctors and 17 are masters, almost all of them are undergoing the doctoral process. There are eight technicians and about 300 students in the licentiate degree and many others in the remaining training courses.

The data collection took place in January 2013 in the two websites of the surveyed nursing schools: Nursing School of the University of Rio Grande (http://www. eenf.furg.br/) and São João de Deus Higher Nursing School of the University of Évora (http://www.uevora. pt/conhecer/unidades_organicas/escolas/escola_ superior_de_enfermagem_sao_joao_de_deus).

The data analysis was grounded on the identification and description of similarities and specificities between the two training courses for nurses, Brazilian and Portuguese. The emerging axes were discussed with basis on the literature.

Throughout the text, one can verify some quotes/ references with more than five years of publication. These inclusions are justified because it is a documentary research, with a certain historicity and, thereby, it becomes pertinent to bring some older quotes.

As for the ethical aspects, due to the fact that the information was accessed by means of the websites of the surveyed nursing schools, there was no need for authorization because it is a material belonging to the public domain. The ethical considerations were satisfied to the extent that the same information was maintained available on the websites.

\section{RESULTS}

We will describe the two training courses for nurses, in Brazil and in Portugal, with basis on some axes: course objective, profile of student, competencies, modality of admission, hourly load and curricular structure.

\section{Brazil}

The FURG offers the bachelor nursing course, guided by the DCNs. Course objective: To provide conditions for a technical, scientific, political, ethical and humanistic learning, contemplating the development of competencies and skills of the professional profile that enable the newly-trained nurse to the use of its potentialities as a generalist nurse, in the solution of problems pertaining to the Nursing, in the performance of administrative, educational and health care-related functions, with respect to: provision of nursing care for human beings, in the promotional, preventive and healing aspects, as well as for rehabilitation and relief of pain and suffering; management of nursing services in hospital, business and collective health institutions; planning, coordination, execution and control of health programs, contemplating the interdisciplinary.

Profile of newly-trained: Generalist, humanist, critical and reflective; qualified for the exercise of the Nursing, with basis on scientific and intellectual austerity and grounded on ethical principles; able to know and intervene on the most prevalent health-disease problems/situations in the national epidemiological profile, with emphasis on the region of operation, i.e., the coastal ecosystem, by identifying the biological, psychological and social dimensions of their determinants, in addition to acting with a sense of social responsibility and commitment to citizenship as a promoter of the comprehensive health of the human being.

Modality of admission: The admission is universal, $100 \%$ through the National Secondary Education Examination (ENEM, as per its acronym in Portuguese), with 35 students for each semester (total of 70 students a year). The ENEM began in 1988, and has the objective of assessing the performance of students at the end of the basic schooling. Students who are completing/already completed high school can participate in it. The University For All Program (ProUni, as per its acronym in Portuguese) is also used as selection criteria for students who want to apply for a scholarship. About 500 universities already use the ENEM as selection criteria for admitting to the higher education level, whether complementing or replacing the entrance examination.

Hourly load: It has a total 4.055 hours, as follows: 2.835 hours of theoretical and practical activities, plus the elaboration of the final project and report of research (Term Paper - TP); 1.020 hours of supervised internships, in the last two semesters and performed in hospital services and in community services; 200 hours of complementary activities, such as: scientific initiations, extension activities, foreign language courses, participation in scientific events, accomplishment of optional disciplines, tutorships and other activities. The hourly load is distributed into nine academic semesters. 
Competencies: They are divided into general and specific. The general are concerned about all courses of the health area and are focused on: health care, decision-making, communication, leadership, administration and management, and permanent education. The specific are related to the context of the nursing course and to the nursing training, with an emphasis on cognitive/political, affective/ethical, psychomotor/critical questions, among others.

Curricular structure: It highlights three disciplines of research and one discipline of elderly care. Among the optional disciplines, one can find Alternative Therapies and Brazilian Sign Language.

\section{Portugal}

The ESESJD offers the licentiate nursing course, guided by the Bologna Treaty. Course objective: To provide the undergraduate students with conditions that allow the development of competencies required to provide general care to people at any moment of the life cycle and in any context; give the undergraduate students the critical and reflective capacity that will allow them to achieve personal and professional development.

Profile of newly-trained nurses and competencies: The profile is determined by means of the competencies established by the Order of Nurses (OE, as per its acronym in Portuguese), which are defined in the Regulation of the Professional Exercise of Nurses (Decree-law n ${ }^{\circ} 161 / 96$, of September $4^{\text {th }}$ ) and in the document entitled "Competencies of Nurses of General Care", elaborated by the Nursing Council. These competencies are divided into three dimensions: Professional, ethical and legal practice; Provision and management of care; Professional development. Each one of these dimensions suggests an action. All the dimensions together comprise the profile of newlytrained nurses.

Modality of admission: The application is annually performed by the National Competition for Access (CNA, as per its acronym in Portuguese), organized by the General Directorate of Higher Education (DGES, as per its acronym in Portuguese), through the National Commission on Access to Higher Education (CNAES, as per its acronym in Portuguese), at the end of the academic year and divided into three phases. A percentage of $50 \%$ of vacancies have a regionalized preference, with priority to those who live in Évora and surrounding areas. In order to compete, it is necessary to: be the holder of a secondary education course/equivalent qualification; perform/have performed, in the last two years, the national exams corresponding the admission tests required for the course/institution to which it will run for, in Nursing: Biology and Geology; perform the prerequisites if they are required by the institution/course to which it will run for; have a medical certificate related to physical and mental ability. Other forms of access: special competition for people older than 23 years; to holders of tests intended to assess the ability to the frequency of the higher education; special competition for holders of higher education courses, middle courses or of a certificate of technological specialization.

Hourly load: The hourly load ceased to be a criterion in the courses adequate to Bologna, and it was replaced by the European Credit Transfer and Accumulation System (ECTS). This system allows counting the totality of the work developed by the student and is an instrument that favors transparency, fosters the relationship among institutions and increases the options for the students. Each academic semester has 30 ECTS and each academic year has 60 ECTS. A course of four years has a total of 240 ECTS. A certain number of ECTS is assigned for each curricular unit (UC, as per its acronym in Portuguese), which corresponds to the calculation of the number of hours that the student has to work to achieve the objectives of the study program. These objectives are specified in terms of competencies to achieve the learning outcomes. The hours of work of the student include the teaching hours (theoretical, practical/ laboratory classes, theoretical-practical classes, seminars), possible internship hours, hours dedicated to the study and accomplishment of works, hours of accomplishment of assessments (tests, written/oral exams and presentations of works). In the University of Évora, each ECTS corresponds to 26 hours of work of the student, in the first cycle (Licentiate); of these, about $50 \%$ are related to the contacts established with the teacher.

Curricular structure: The course is structured on the reference of the profile of competencies defined by the OE for the grant of the professional title. All the curricular units contribute, in an articulate and progressive way, to the development of professional competencies required for the admission. The course is distributed into eight semesters and is based on the alternation among the curricular units with theoretical 
and theoretical-practical nature and clinical teaching. The first two semesters comprise a set of theoretical and theoretical-practical curricular units, which are structuring for the comprehension of the Nursing as a discipline and profession. In each one of these semesters, there are optional curricular units, which are more identified with the purposes of the semester. The remaining six semesters are structured in such a way that the odd semester is constituted of theoretical and theoretical-practical curricular units, and the even semesters are constituted of clinical teaching, thereby embodying the above mentioned alternation. There are optional curricular units only in odd semesters, which obey the enunciated principle. The exception to this rule takes place in the seventh semester, which encompasses four curricular units with theoretical character and two clinical teachings. Clinical training takes place in contexts of health services that follow the patterns required by the school. The clinical teachings give privilege to small groups, closer tutorial guidance, supervision of performance, development of clinical competencies essential to the provision of care actions, development of competencies, reflection in/on action, as a way to turn it into a promoter of development.

The curriculum plan of the licentiate nursing course is formed by several scientific areas, with predominance of the scientific area of Nursing. The distribution of compulsory ECTS by scientific areas is as follows: 179 ECTS are from Nursing and 43 ECTS are from areas such as Medicine, Sociology, Philosophy, Ethics, Psychology and Management. Of the 53 optional ECTS offered, 27 ECTS are from Nursing, and the others are from the areas of Foreign Language and Literature, Computer Science, Statistics, Business Sciences and Arts. One should highlight the optional disciplines such as entrepreneurship; arts; music and foreign languages. From the compulsory disciplines, one should highlight: Clinical Reasoning in Nursing; Family Nursing; Development throughout life; Rehabilitative Nursing and Prospects of development of the Nursing.

\section{Discussion}

Similarities in the nursing training between Brazil and Portugal

The analyzed nursing courses are inserted into the higher education in the two countries in question.
The objectives of the analyzed courses are convergent, since they direct the acquisition of technical, relational, ethical and contextual competencies, among others. Both courses have elaborated their objectives from legal provisions: the Nursing School of the FURG, according to the DCNs, and the ESSJD, according to the standards of the Bologna Process. In either assessed courses, the profile of newly-trained nurses indicate multiple competencies, besides other characteristics essential to the training of nurses. The act of thinking of competencies means to articulate much knowledge in the solvability of problems and in the confrontation of unexpected situations, as well as mobilizing intelligence towards the occupational challenges ${ }^{(13)}$.

Another similar point is that there are disciplines aimed at health education in both courses. The inclusion of education in/for health in the nursing training is a tool able to promote the learning of abilities for the nursing professional to guide/educate people/users in several aspects, mainly when they are related to self-care ${ }^{(12)}$

The presence of optional disciplines in the two courses should also be highlighted. In the Brazilian course, there are disciplines on alternative therapies and Brazilian Language of Signals (LIBRAS). One should value that future nurses know about Western and Eastern ways of health care, in order to enable them to have a critical judgment in the choice of the most appropriate modality and provide integrated and evidence-based health care in their professional practice. They need to be able to discern when the alternative/complementary therapies are appropriate or not to help in the treatment of a particular disease. This professional judgment and critical thinking should be reinforced during the training, since each modality of care, whether Eastern and/or Western, has limitations ${ }^{(14)}$.

The learning of the Brazilian Language of Signals (LIBRAS) should be encouraged among nursing students, as a means of inclusion and an opportunity to provide more appropriate care to people with hearing needs, as advocated by the Decree $n^{\circ} 5.626$, of December $22^{\text {nd }}, 2005,{ }^{(15)}$ of the Brazilian Ministry of Education.

In the course of Portugal, there are optional disciplines focused on entrepreneurship and other focused on other areas of knowledge such as arts, music and foreign languages. Such knowledge 
directs the need for interdisciplinarity in the nursing training. The complexity of care actions targeted to health establishes the teamwork in interdisciplinary perspective as ones of the priorities, in the pursuit of shared solutions for the comprehensiveness of the health care with the purpose of overcoming disciplinary borders (16).

\section{Specificities in the nursing training in Brazil}

A first specificity is related to the admission process. The fact of the form of admission in the higher education is $100 \%$ through the ENEM provides opportunities for any Brazilian citizen, in any part of the country, thereby eliminating the percentages that were ensured to those who live in the city of the course or in surrounding areas. This situation turns the accessibility of the higher education into a universal chance ${ }^{(2)}$.

The presence of disciplines focused on investigation is a second specificity of the training of Brazilian nurses. These disciplines meet the DCNs, in their Article 12, when it requires that, in order to conclude the Undergraduate Nursing Course, the student should elaborate a scientific work, under faculty guidance ${ }^{(3)}$. Nursing, as a profession and discipline, has made use of research as a way to improve the practice, supported by the acquisition of new knowledge. It is necessary that there is training and encouragement towards the research at the undergraduate level, since it tends to direct the professional exercise of the nurse to the field of care, with an expanded vision that goes beyond the everyday practice ${ }^{(17)}$.

A third specificity is the presence of a discipline focused on the care of elderly people. By considering that the elderly population has, proportionately, the larger growing in Brazil and worldwide, there is the need for future nurses to know how to take care of elderly people, thereby knowing their peculiar characteristics. In their Article 16, the DCNs show the teaching areas in Nursing: biological and health sciences, human and social sciences, nursing care, nursing administration and nursing teaching. In nursing care, the theoretical and practical content should direct the teaching of the provision of care, individually and collectively, for children, adolescents, adults, women and elderly citizens, taking into account the sociocultural, economic and ecological determinants involved in the health-disease process and observing the ethical, legal and humanistic principles ${ }^{(3)}$.
The existence of complementary activities is a further specificity; according to the DCNs, in their Article 8 , these are mechanisms to take advantage of knowledge acquired by the student through independent studies and practices, face-to-face and/or distant, such as tutorships and internships, scientific initiation programs, extension programs, complementary studies, participation in events, courses in related areas ${ }^{(3)}$.

Finally, another specificity concerns the fact of the teaching is based on the qualification of the future nurse for acting on health services of the Brazilian Unified Health System (SUS), with focus on the student. According to the sole paragraph of the Article 15, the training of the Nursing professional should meet the health needs, with emphasis on the Brazilian Unified Health System (SUS) and ensure the comprehensiveness of care and the quality and humanization of attendance ${ }^{(3)}$.

\section{Specificities in the nursing training in Portugal}

A first specificity is related to the admission process. There is the requirement for a medical certificate for the admission to the nursing course, under the form of response to an individual health questionnaire, with a view to proving the ability of interpersonal communication, the lack of a mental, sensory or motor disability that can seriously interfere with the functional ability and of communication interpersonal to the point of preventing their own learning or of other people. It can be proved through medical declaration, delivered in the act of enrollment, in an indispensable form, and constitutes in a requirement of the General Directorate of Higher Education of the Ministry of Education and Science ${ }^{(18)}$.

Another singularity is the use of the European Credit Transfer System (ECTS), which come from the European Credit Transfer and Accumulation System (18), which allows considering the overall amount of work of the student, thereby valuing the entirety of its investment to conclude the course in an effective way. The ECTS is an instrument that produces the necessary conditions for the similarity among the European educational establishments. Its application eases up the recognition and transferability of academic results of students, through the use of measures comprehended in the same way by all stakeholders.

A further specificity is the presence of compulsory disciplines such as: Clinical Reasoning in Nursing 
and Prospects of development of the Nursing, which are core themes for the professionals in the scope of the nursing teaching and practice ${ }^{(19)}$. Another compulsory discipline is Rehabilitative Nursing, which contributes in the training of nurses to care of patients undergoing rehabilitation, in the acute or chronic phase of a disease, with actions directed to favor the recovery and adaptation to the limitations imposed by the disability and to meet the needs of patients/families, such as, for example, the functional, motor, psychosocial and spiritual.

The basis is focused on clinical teaching. In nursing training, this type of teaching is constituted as an important period, by enabling the student to acquire and consolidate knowledge, develop clinical competencies, in addition to being an initial space for the socialization process and for the professional identity ${ }^{(20)}$. Such teaching takes place in contexts selected according to the quality patterns of the school, by establishing relationships with nurses, where the actual and effective learning takes place.

\section{Conclusions}

We consider that the objective was achieved. The contributions of this study to the nursing field are: understanding of nursing training in Brazil and in Portugal, which is important to ease the exchange of students, between the two countries; smoothing element, when a student needs to be transferred from one country to another, which might serve to help him/her in the face of the course coordination, in relation to increased absorption of the disciplines attended; way to the emergence of reflections to the two countries involved in the research, when it comes to the need for disciplines focused on research, on the teaching directed to elderly people and, lastly, on the fact of the basis of the nursing training is grounded on clinical teaching.

\section{CONFLiCTS OF INTEREST}

"The authors declared that there is no conflict of interest of any nature".

\section{REFERENCES}

1. Santos SSC. Currículos de enfermagem do Brasil e as diretrizes - novas perspectivas.Rev Bras Enferm. 2003;56(4):361-364. http://dx.doi.org/10.1590/S003471672003000400009
2. Brasil. Ministério da Educação. Lei n. ${ }^{\circ}$ 9.394, de 20 de dezembro de 1996: estabelece as diretrizes e bases da educação nacional. Diário Oficial da União, Brasília (DF) 23 dez 1996.

3. Brasil. Ministério da Educação. Conselho Nacional de Educação. Câmara de Educação Superior. Resolução n. 3, de 7 de novembro de 2001. Institui as diretrizes curriculares nacionais do curso de graduação em Enfermagem. Diário Oficial da União, Brasília (DF)9 nov. 2001.

4. Lopes Neto D, Teixeira E, Vale EG, Cunha FC, Xavier IM, Fernandes JD et al . Aderência dos Cursos de Graduação em Enfermagem às Diretrizes Curriculares Nacionais. Revista Brasileira de Enfermagem. 2007; 60(6): 625-634. http:// dx.doi.org/10.1590/S0034-71672007000600003

5. Brasil. Ministério da Educação. Conselho Nacional de Educação. Câmara de Educação Superior. Resolução no 4, de 6 de abril de 2009. Dispõe sobre carga horária mínima e procedimentos relativos à integralização e duração dos cursos de graduação em Biomedicina, Ciências Biológicas, Educação Física, Enfermagem, Farmácia, Fisioterapia, Fonoaudiologia, Nutrição e Terapia Ocupacional, bacharelados, na modalidade presencial. Diário Oficial da Uniãol.Brasília (DF), 7 abr. 2009.

6. Fernandes JD. Expansão de cursos/vagas de Graduação em Enfermagem e a qualidade do processo de formação da(o) enfermeira(o).Rev. bras. enferm. 2012; .65 (3):395-396.

7. Carta de Belém/PA, para a Educação em Enfermagem Brasileira. ABEn. Documento Oficial. Rev Bras Enferm. 2012; 65(4): 696-8. http://dx.doi.org/10.1590/S003471672012000400022

8. Cabral IE, Teixeira E. Uma década de Diretrizes Curriculares Nacionais:conquistas e desafios. Rev Bras Enferm. 2012; 65(4): 555-6. http://dx.doi.org/10.1590/ S0034-71672012000400001

9. Mendes FRP, Mantovani MF. Ensino de enfermagem em Portugal: contributos para sua história.Cogitare Enferm 2009 Abr/Jun; 14(2):374-8. http://dx.doi.org/10.5380/ ce.v14i2.15632

10. Portugal. Ministério da Ciência, Inovação e Ensino Superior. Decreto-Lei no.42/2005. Diário da República, Lisboa, 22 fev 2005. http://www.dges. mctes.pt/NR/rdonlyres/90DBE647-5CB6-4846-B88F101180D9E425/1131/DL422005.pdf

11. Cellard A. A análise documental. In: Poupart J, Deslauriers JP, Groulx LH, Laperrière A, Mayer R, Pires AO. A pesquisa qualitativa: enfoques epistemológicos e metodológicos. Petrópolis: Vozes; 2010.

12. Ordem dos Enfermeiros. Regulamento do Perfil de Competências do Enfermeiro de Cuidados Gerais. Lisboa: ordem dos enfermeiros. [monografia na internet]. 2012 [acesso em 13 jan 2013] Disponível em <http://www.ordemenfermeiros.pt/publicacoes/ Documents/divulgar\%20-\%20regulamento\%20do\%20 perfil_VF.pdf>

13. Lima MM, Almeida AB, Giovannetti MO, Backes VBS, Kloh D. Produção do conhecimento acerca da formação do enfermeiro: um estudo bibliométrico. Rev Bras Enferm. 2012; 65(3): 522-8. http://dx.doi.org/10.1590/S003471672012000300019

14. Pinzón-Pérez H, Palacio LMA. Complementary and alternative medicine: a new professional arena for clinical nurse specialists and health educators. SaludUninorte. 2012; 28 (1): 162-170. 
15. Brasil. Ministério da Educação. Instituto Nacional de Estudos e Pesquisas Educacionais Anísio Teixeira. Documento orientador das comissões de avaliação in loco. 2012 [acesso em 15 jan 2013] Disponível em <htt:www. portal.inep.gov.br>

16. Lourenção DCA, Benito GA. Competências gerenciais na formação do enfermeiro. Rev Bras Enferm. 2010; 63(1): 91-7. http://dx.doi.org/10.1590/S003471672010000100015

17. Erdmann AL, Leite JL, Nascimento KC, Lanzoni GMM. Vislumbrando a iniciação científica a partir das orientadoras de bolsistas da Enfermagem. Rev Bras Enferm, Brasília 2011; 64(2): 261-7. http://dx.doi.org/10.1590/S003471672011000200007
18. Universidade de Évora (PT). Despacho (extracto) $\mathrm{n}^{\circ}$ 13495/2008, de 14 de maio de 2008: adequação ao Processo de Bolonha do curso de Licenciatura em Enfermagem pela Universidade de Évora. Diário da República, Lisboa 2008 maio 14 ; (93) 2a série: 21647-49.

19. Cerullo JASB, Cruz DALM. Raciocínio clínico e pensamento crítico. Rev. Latino-Am. Enfermagem. 2010; 18(1):[06 telas] www.eerp.usp.br/rlae

20. Araújo O, Martins C, Braga F, Macedo AP, Oliveira C, Rosário R. Supervisão em contexto clínico: o testemunho dos estudantes sobre o(s) modelo(s) vigente(s). Revista de Formación e Innovación Educativa Universitaria. 2012; 5(2) 112-121. [acesso em 19 jan 2013] Disponível em http:// repositorium.sdum.uminho.pt/bitstream/1822/19639/1/ Refiedu-Artigo\%20publicado.pdf 